Understanding Responses to the Political Context of Health Inequalities in

Research and Policy: Can post-structural theories of power help?

Authors: Smith, K.E. ${ }^{1^{*}}$

${ }^{1}$ Global Public Health Unit, School of Social \& Political Science, University of

Edinburgh. "Corresponding author (email: Katherine.Smith@ed.ac.uk, telephone:

$01316511323)$

Word count: 9,818 


\section{Understanding Responses to the Political Context of Health Inequalities in Research and Policy: Can post-structural theories of power help?}

\section{Abstract:}

It is now widely accepted that health inequalities are directly linked to inequalities in power and material resources. Reflecting this, persuasive accounts of both the production of health inequalities and the failure of high-income countries to reduce these inequalities have been underpinned by references to structural (particularly neo-Marxist) theories of power. Such accounts highlight the importance of macrolevel political and economic policies for health outcomes and, in particular, the unequally damaging impacts of policy reforms collectively referred to as 'neoliberal'. This paper draws on interviews with researchers, civil servants, politicians, documentary makers and journalists (all of whom have undertaken work concerning health inequalities) to examine what these conversations reveal about these actors' perceptions of, and responses to, the political context of health inequalities in the UK. In so doing, it illustrates the fluid and networked nature of political 'power' and 'context'; findings that point to the potential utility of post-structural theories of power. This article argues that, if conceived of in ways which do not deny power differentials, post-structural theories can help: (i) call attention to 'neoliberal' inconsistencies; and (ii) explain how and why individuals who are critical of dominant policy approaches nonetheless appear to participate in their on-going production.

\section{Abstract word count: 200}

Keywords: Power; post-structural; political context; health inequalities; neoliberal; policymaking. 


\section{Introduction}

For many academics concerned with health inequalities, the importance of political context in shaping policy decisions is unquestionable (e.g. Coburn 2004; Muntaner and Lynch 1999; Navarro and Shi 2001; Navarro, Muntaner et al. 2006; Navarro 2007; Schrecker and Bambra, 2015). Whilst differing to some extent in their analyses, these authors all argue that policies in most countries are made in the interests of dominant, elite groups, rather than the majority of the population. Their accounts also suggest that the social and economic policies implemented in developed countries, such as the UK, over the past fifty years or so, share some important features (the privatisation of public sector goods and services, the removal of public support for key industries and of some employment rights, and a shift in macro-economic policy towards a more monetarist focus) which can collectively be understood to constitute 'neoliberalism'. From this perspective, the fact that the UK's policy commitments to reducing health inequalities appear, by many measures, to have failed (Mackenbach, 2010) can easily be explained by reference to the hegemony of a neoliberal ideology and the underlying interests of dominant, elite interests (see, for example, Carlisle 2001; Scott-Samuel 2004).

Underpinning such accounts, is a 'structural' conceptualisation of power, in which power is understood as an inscribed capacity, something which is appropriated by particular individuals or organisations. From this perspective, power is configured across society so that particular individuals and organisations 'possess' power, which they can use to achieve certain outcomes, whilst others are 'powerless' (or, at least, 
far less powerful). Power is always possessed but not always exercised and, as a result, power is perceived as 'always potential' (Allen, 1997). Marxist and NeoMarxist accounts tend to be informed by this way of thinking, viewing power as something that is located in particular institutions and sections of society (e.g. capitalist organisations and the 'ruling classes'). Hence, even though Lukes' (1974) famous 'three faces' of power suggests that the manner in which power is exercised, and is observable, may vary (from clearly observable behaviours, to agenda setting, to the sophisticated manipulation of others' preferences), from a Marxist perspective the capacity to exercise power is understood to emerge from material resources and interests. It is therefore relatively easy to identify who is 'powerful' (and who is not).

In contrast, accounts of power that might collectively be labelled 'post-structural', portray power in a far more fluid manner, as something which is exercised but not appropriated. Informed by the ideas of thinkers such as Henri Lefebvre and Michel Foucault, post-structural accounts suggest power cannot be possessed and is rather, 'something which passes through the hands of the powerful no less than through the hands of the powerless,' (Allen, 1997, p. 63). Rather than being inscribed in particular individuals or organisations, power is seen as far more diffuse and mobile; it is continually circulating and allows more possibility for the role of individual agency. There are multiple accounts of power that can be classified as 'poststructural' and it is not possible to review them all here so this article focuses specifically on one strand of this genre, Actor-Network Theory (ANT), which views power as an effect of complex networks. For example, ANT theorists such as John 
Law, Bruno Latour and Michel Callon, argue that although we tend to refer to particular entities as single, powerful actors (such as the 'government' or 'political context'), these are in fact an effect of diverse but successful networks:

'[I]f a network acts as a single block, then it disappears, to be replaced by the action itself and the seemingly simple author of that action. At the same time, the way in which the effect is generated is also effaced: for the time being it is neither visible, nor relevant. So it is that something much simpler a working television, a well-managed bank or a healthy body - comes, for a time, to mask the networks that produce it.' (Law 1992, p385)

If we replace the 'working television' or 'healthy body' referred to in the above quotation with 'government' or 'neo-liberal economy', we begin to see how political context is understood by actor-network theorists. Networks, therefore, usually only become visible when they fail or, actor-network theorists argue, when the interactions involved in a network are carefully examined and uncovered (for a more detailed explanation of actor-network theory see Law 1992; and Latour 2005). Actor-network theorists are interested in how it is that some kinds of interactions, 'more or less succeed in stabilizing and reproducing themselves: how it is that they overcome resistance and seem to become 'macrosocial'; how is it that they seem to generate the effects such as power, fame, size, scope, or organization with which we are all familiar' (Law 1992, p380). This approach, then, does not deny then that power differentials exist but calls our attention to the need to 'understand how structures are continually (re)produced through the process of interaction' and to 
identify 'the processes that give rise to power as an effect' (Murdoch and Marsden, 1995, p372).

This is precisely the kind of work that this article attempts to undertake and, in so doing, it seeks to draw attention to the various ways in which research, and researchers, shape and are shaped by ideas about the political context in which we live and work. It argues that the empirical findings from interviews with a range of research and policy actors provide compelling grounds for taking post-structural accounts of power more seriously within health inequalities. The interviews provide insights into how researchers, civil servants, politicians, documentary makers and journalists who have undertaken work concerning health inequalities in the UK think about, and respond to, political 'power' and 'context'. The analysis underlines the difficulties such actors face in trying to disentangle and critically distance themselves from dominant ideas due to the networked and discursive dynamics of power. The paper is careful not to dismiss the value of structural accounts of power for understanding, and responding to, health inequalities (and, indeed, refers to Lukes' (1974) account of power in discussing some aspects of the findings). However, it argues that post-structural thinking is useful in drawing attention to the role that individual actors and organisations play in enacting (or resisting) particular political and economic ideologies (Keck and Sikkink 1998; Campbell 2002; Larner 2003). This helps explain how and why individuals who are critical of dominant political ideas nonetheless appear to participate in their on-going production. 
Following this introduction, the article briefly outlines the approach taken to collecting interview data, before reflecting on the specific ways in which interviewees described how they viewed the political and social contexts within which they were situated. The common theme linking these accounts is a belief that such contexts were unfavourable to tackling health inequalities, both because there was believed to be a lack of public interest in the issue and because many interviewees perceived there to be overpowering and insurmountable ideologies working to minimise the influence of some of the research-based ideas about health inequalities that they supported. Here, it seems clear that actors' readings of political and social 'contexts' appears to influence their actions and interactions; they are, therefore, doing more than passively interpreting external 'contexts'. Rather, actors' perceptions of external realities play an active role in the construction and maintenance of these perceptions. The empirical material presented, which is drawn from interviews with researchers, civil servants, politicians, documentary makers and journalists involved in work directly relating to health inequalities, hopefully illustrates some of the factors which allow political 'contexts' to appear to function as singular, unchallengeable actors/ideologies (such as 'neoliberalism'). The final part of the article reflects on what this kind of poststructural account of power and political context means for health inequalities researchers in practice, particularly those researchers who (like the author) are committed to working to reduce health inequalities. 


\section{The empirical data}

The paper draws on data from a larger research project exploring UK research and policy on health inequalities (Smith, 2013) which involved interviews with 112 individuals involved in health inequalities research and policy (or media coverage of this) in the UK between 1997 and 2012 (see Table 1). The larger project was also informed by thematic and semiotic discourse analysis of 59 relevant policy documents (Smith, 2013) but the focus here is on how interviewees described the 'political context' in which they lived and worked and how this, in turn, implies a need to take post-structural accounts of power seriously.

Table 1: A breakdown of interviewees' professional positions

\begin{tabular}{|l|l|l|l|}
\hline Interviewees' primary professional position & Number of & Number of & Total \\
(many individuals also had experience of & interviewees & interviewees & number of \\
\hline Academic researchers & $2005-2007$ & $2011-2012$ & interviewees \\
\hline $\begin{array}{l}\text { Individuals working in policy settings (largely } \\
\text { civil servants) }\end{array}$ & 10 & $20\left(2^{*}\right)$ & 48 \\
\hline Researchers working in independent/private & 5 & $15\left(2^{*}\right)$ & 23 \\
research organisation (including think tanks) & & 1 & 6 \\
\hline Public sector researchers / policy advisors & 5 & 3 & 8 \\
\hline Journalists or media communications staff & 5 & 5 & 5 \\
\hline Politicians (including ministers) & 4 & 0 & \\
\hline
\end{tabular}




\begin{tabular}{|l|l|l|l|}
\hline Research funders & 3 & 4 & 7 \\
\hline Public health 'knowledge brokers' & 0 & 3 & 3 \\
\hline Senior staff in third sector / advocacy & 0 & 4 & 4 \\
organisations & & $\mathbf{5 4}\left(\mathbf{4}^{*}\right)$ & $\mathbf{1 1 2}$ \\
\hline Total & $\mathbf{6 2}$ & & \\
\hline ( $\left.{ }^{*}\right)$ Indicates the number of interviewees in 2011-2012 who had also been interviewed in \\
$2005-2007$.
\end{tabular}

The interviews were semi-structured and took place in two batches (the first in 20052007, when a Labour government was in power in the UK, and the second in 20112012, when a Conservative-Liberal Democrat coalition was in power). The second period of interviewing included conducting follow-up interviews with four key interviewees who had been interviewed in 2005-2007 (see Table 1).

The majority of interviews took place in a private room where, for the duration of the interview, only the interviewee and the researcher were present (two interviews were joint interviews with two interviewees and four were conducted by telephone, all at the request of interviewees). A themed interview schedule was employed which focused questions around health inequalities research, policy and the interplay between the two. The interviews varied in length, lasting between 45-150 minutes (most were around 60-80 minutes). The research was conducted in line with University of Edinburgh's ethical guidelines. All interviews were digitally recorded and transcribed verbatim, before being thematically coded in the 
qualitative data analysis programme, Atlas.ti, using a coding framework that was developed iteratively, via analysis and re-analysis of the transcripts.

\section{Interviewees' perceptions of social and political 'contexts'}

In this section, we will see that, although many interviewees referred to a political context in ways which evoked a structural understanding of power, their accounts of what exactly this 'context' was varied. The consistent theme in these various accounts was a belief that, however 'contexts' are perceived and understood, they have not recently been favourable to achieving reductions in health inequalities. One aspect of this, referred to by most health inequalities researchers, was a perceived lack of media, think tank and non-governmental organisation (NGO) interest in health inequalities (i.e. a lack of interest in health inequalities, and social and economic inequalities more broadly, within the key institutions commonly understood to both reflect and inform the social, political and economic contexts in which we live).

In total, only one interviewee said s/he felt health inequalities was an issue in which there was substantial media interest and only one (other) interviewee suggested that any 'think tanks' had taken up the issue. Similarly, most interviewees struggled to come up with examples of any charities or NGOs that they felt were actively campaigning about the issue, as Table 2 illustrates. 
Table 2: The perceived lack of lack of media, NGO and think tank interest in health inequalities amongst researchers

\begin{tabular}{|c|c|}
\hline $\begin{array}{l}\text { Group or } \\
\text { institution }\end{array}$ & Illustrative quotations \\
\hline The media & $\begin{array}{l}\text { Academic: 'People get very bored with inequalities, the media gets very } \\
\text { bored. [...] They even get bored of inequalities getting worse 'cause } \\
\text { they've got used to that, it's like, 'we've had that story.' And you go, } \\
\text { 'yeah but they're getting worse still...' 'But weren't they the worst ever } \\
\text { five years ago?' And you go, 'yes, but that was five years ago and } \\
\text { they're now worse.' So coping with fatigue over... that is... quite } \\
\text { difficult.' }\end{array}$ \\
\hline NGOs & $\begin{array}{l}\text { Academic: 'I'm probably missing a trick but I can't think of one or two } \\
\text { major organisations that have [lobbied for action to reduce health } \\
\text { inequalities]' }\end{array}$ \\
\hline Think tanks & $\begin{array}{l}\text { Academic: 'For some reason, the think tanks are not getting into it } \\
\text { [health inequalities]. I don't know why not, actually. [...] We've... got } \\
\text { DEMOS and IPPR and all the rest of it. Very interesting... organizations } \\
\text { but none of them... I mean I've vaguely tried to get them interested in } \\
\text { health inequality actually and [Blank], who does the PR for the [Blank- } \\
\text { research group], was constantly bombarding them with things, and I } \\
\text { think they used to come to the odd meeting but they never engaged with } \\
\text { us. So, for whatever reason, they've decided it's not something to really } \\
\text { get into.' }\end{array}$ \\
\hline
\end{tabular}


The perceived lack of interest in health inequalities amongst these various institutions and sectors was believed to be deeply problematic by many of the interviewees, both because it lessened the pressure on politicians and civil servants to follow-up rhetorical commitments to reducing health inequalities and because it limited the mechanisms (and potential audiences) for the circulation of researchbased ideas about health inequalities. This underlines the continued importance of reflecting on the role that Lukes' 'second', agenda-setting dimension of power plays in drawing our attention towards particular issues and away from others.

Such perceptions left many interviewees to conclude that the only actors really pushing to reduce health inequalities are academic researchers and a few sympathetic politicians and civil servants. This context was held up in stark contrast to the memories that many interviewees described having of the situation prior to 1997. The picture painted of this period was often one in which the government's decision to reject the materialist findings of the government-commissioned Black report into the causes of health inequalities (Black et al. 1980) had served to ignite interest in the issue of health inequalities amongst a wide range of audiences, including the media, NGOs and public health practice communities. The stories told by interviewees about this era usually focused on the ways in which different actors had come together around the aim of ensuring that the reduction of health inequalities was a policy issue by the time that the New Labour government was elected. Many of these descriptions evoke a sense in which the period between 1979 and 1997 (a period dominated by Margaret Thatcher's and, for a shorter 
period, John Major's Conservative governments) was marked by a sense of passion, excitement and relative unity within the health inequalities research community.

In some ways, the period from 1997 onwards, when health inequalities came back on to the formal policy agenda with the Labour Party's election success on the back of a manifesto which included a commitment to reducing health inequalities, was portrayed in almost precisely the opposite way; whilst all interviewees recognised, and seemed pleased, that the reduction of health inequalities had now become (and remains) a clear policy aim, there was very little belief that there was much of a 'campaign' around particular ideas about how to achieve reductions in health inequalities. In part, the lack of unity around a particular 'message' was seen to reflect the fractured nature of the research community but it was also believed to result from the seductive power of funding opportunities (a point returned to later in this article).

For the majority of interviewees, the perceived lack of interest in ideas about how to reduce health inequalities amongst individuals in the media, NGOs and think tanks was reflective of a broader lack of interest in the issue amongst the wider public. This was articulated in two, rather different ways. The first, as illustrated in the following quotation, was a sympathetic reflection that those most negatively affected by health inequalities were likely to be facing more immediate and pressing concerns than their relative life expectancy compared to others: 
Academic: 'I don't think it's an issue that you can kind of keep getting people going to the barricades on because it's actually, if you are in a tough social situation, it's hard enough without thinking, 'oh well, I'm only going to live to be seventy-two instead of seventy-five...'

Sentiments very close to those expressed by the above interviewee were evident in interviews with around a quarter of the academic interviewees and two policy advisors (both of whom were based in Scotland). The second way in which a perceived lack of public interest was commented upon was much less sympathetic, evoking a sense of the 'moral underclass discourse' that Levitas (2004) identifies in New Labour policies. For example:

Broadcast journalist: 'Certainly when it comes to health inequalities, the people who are suffering from health inequalities are the people who consume the least news, you know... the deprived areas - they're the people who are watching the least news so, in a way, by doing that, they're influencing their own situation because... we would be trying to present a report which very few people would want to watch so... I mean certainly in terms of newspapers, if they know that that story isn't going to get people to buy their newspaper, they won't print the story, or they won't devote much time to it anyway.'

The above quotation extends the notion of individual responsibility for health inequalities beyond the usual focus on lifestyle and behavioural 'choices' (Katikireddi 
et al, 2013) to the decisions people make about the programmes they watch and the newspapers they read, which adds another dimension to Crawford's (1977) analysis of 'victim blaming' discourses. Whilst this particular interviewee was the only one to specifically suggest that individuals' decisions about media consumption contributed to the paucity of public and political concern about health inequalities, around a quarter of the interviewees based in policy and academia expressed the view that public apathy about health inequalities contributed to (and was therefore partially responsible for) the lack of interest in the issue amongst other policy actors (and there was a marked increase in this claim between the two batches of interviews).

More specifically, the perception which is perhaps most pertinent to this article is the widespread belief that interviewees expressed regarding political, media and public disdain for policies aimed at reducing inequalities in wealth or power. This is illustrated by the quotations in Table 3. This speaks to Lukes' (1974) third dimension of power, in which people are persuaded that their own interests reflect those of dominant elites and, consequently, acquiesce in their own domination.

It is important to highlight that this perception was articulated relatively frequently within the data and only two interviewees suggested that there was some public appetite for more egalitarian economic policies (and no interviewees claimed there was any media or political appetite for such policies). In effect, this means that many health inequalities researchers felt that the kinds of redistributive, materialist policies that research suggests they believe most likely to contribute to reducing health inequalities (Smith and Kandalik Eltanani, 2014) are also the kinds of policies 
which interviewees believed to be most incompatible with the dominant social and political 'context'. Indeed, a number of interviewees claimed these kinds of research-based ideas had effectively been 'blocked' by hostile political and social 'contexts'. For example:

Senior academic researcher: 'At one level you can think of... interventions that might operate within a kind of existing economic and political context, and those interventions that might challenge... an existing economic and political... context. So, there are, there are a whole range of potential interventions around redistribution of wealth that might... actually be really quite effective [...] but I think one of the things that... happens when those kind of obvious policy implications are pulled out of research is that... they're then placed within the context of a particular political economy and... they cannot be implemented within that context.'

The above interviewee described his/her perception that the wider political and social 'context' had acted as a barrier to some research-based ideas about health inequalities particularly clearly but similar sentiments are also evident in the quotations in Table 3.

Table 3: Perceptions of lack of public, political and media support for more egalitarian policies

Illustrative quotations: 
Academic: 'I think... a government that isn't... keen to pursue issues around... income redistribution... you know, that's a reasonably popular thing to not do. Who wants to pay more taxes? And... if taxes go up for the richest, somehow or other everybody seems to feel they're being affected by it so, unless the government is prepared to tackle that at a media level, nobody's going to be unhappy with their decision... not to change taxation.'

Journalist: 'I mean if you look at the countries with the smallest wage differentials, then they're the countries with the lowest health inequalities so that's something that is clear. Are we ready for that in this country? I don't think so [...] I mean tax is usually the issue that... our elections get decided on and I can't imagine anybody going to the electorate and saying, 'well actually, we think that people who are earning above thirty-thousand pounds should be taxed an extra five percent... to help people at the lower levels and close these differentials and abolish health inequalities,' because I think the mentality in this country is, 'well, I don't want that,' you know, 'I'm okay; let these people look after themselves.' So I can't see that as being something that's going to be very popular.'

Academic: 'We're not willing to live in societies where there's equality in other domains, other than health. So we're not willing to live in societies where there's equality of wealth or equality of income [...] and... equality of housing or equality of access to other services. We're only willing to live in a society where we have, ostensibly, equality in health status and equality in children's education - those are 
about the only things where we're willing to accept equality. In virtually every other domain of life, we don't want equality; we actually worship inequality. [...] It's a winner-take-all society we're creating [...] that's the kind of place we're living in. If you can make a hundred million because of some good idea, good luck to you. And the fact that a head teacher has to look after a comprehensive school with fifteen hundred pupils in it and gets paid sixty thousand pounds a year and doesn't really have any prospects of increasing that, nobody seems to think that's an injustice, between that pay and the pay of a major footballer. To me, that's a massive injustice, and it's not till we get our values in society sorted out that... we can begin to make progress.'

The opinions expressed above have been regularly put forward in academic literature (e.g. Levitas 2001; Carmel and Papadopoulos 2003) and so it is no surprise to find them well represented in the data, especially within the transcripts of interviews with academics. Much like some of the structural accounts of power that were discussed in the introduction, these data evoke a sense in which a concrete 'political context' is limiting not only the prospective policy options for reducing health inequalities but also the related public and political debates about social and economic inequalities. Yet, it is rarely, if ever, clear in the data who or what is perceived to be in control of the agenda. For example, the illustrative quotations in Table 3 refer to 'government', 'media' and 'society' as key actors but, although all three of these 'actors' are made up of a range of other actors, there is almost no reflection within the data on the heterogeneity and complexity underlying these terms or on the fact that interviewees were themselves constitutive of these various 
groups. In the following two quotations, the interviewees suggest that even senior civil servants and ministers are actively constrained by 'the government', without reflecting on who or what 'the government' is (if it is not senior civil servants and ministers):

Academic: 'I recently had a rather unpleasant exchange with [senior person in the] Health Inequalities Unit at the Department of Health when I tried to get these views across, 'cause even though that person is a very estimable person, s/he is of course constrained by what the government will permit and... of course... the government will only permit its civil servants to go so far in doing anything that might challenge its fundamental tenets.'

Academic: 'I am not convinced, despite... some appealing commitments, committing statements, on the part of government... that even the Ministers feel that they have much authority in how... changes might be introduced. I think quite a few of them are... highly intelligent, they... know that inequalities in health is a very complex issue, but they, between the lines, they can read the unwillingness of the government to oblige... some of those in power to... change tack and to move in a different direction.'

The sentiments in these quotations are reinforced by a range of political diaries and autobiographies that reflect on the limits to ministerial, and even prime ministerial power (e.g. Blair, 2011; Mullin, 2010). On the one hand, this could be interpreted as supporting the idea that power is amorphous, fluid and networked (no one 
individual or institution was identified by interviewees as 'having' power; rather everyone seemed to be operating in a complicating network that was constraining their choices). Yet, there is, as the above quotations illustrate, a common tendency in the data for interviewees to refer to particular groups, such as 'the government', as if they are singular entities invested with the power to implement policies of their choosing.

The consequence of this, as Latour (2005) suggests, is a belief that little, if anything, can be done to challenge the situation. In other words, at least some of the power associated with 'government' emerges from a relational process whereby actors are successfully persuaded that 'government' is a single, Goliath-like actor that cannot be challenged (and then act accordingly). Indeed, the only times in which the power of 'government' is significantly challenged within the interview data is by interviewees who suggested that 'governments' were controlled by even more powerful actors, such as global financial actors. For example:

Academic: 'Governments right now... are influenced by multi-national corporations [...] and... it's the minority in affluence that are able to... press them and to make sure they implement certain policies. [...] These policies are... a sort of coherent package that is going to be implemented in virtually every country, with few exceptions. So... even a socialist government cannot address issues of poverty, of inequality effectively.' 
Like the above interviewee, many of the academic interviewees linked their perceptions of a restricted policy environment within the UK to the development to broader, global economic processes and the 'powerful reach' of large financial institutions such as multi-national corporations, the IMF and the World Bank. Yet, like references to the 'government', references to the 'global' processes via which the UK's political context was being shaped tended to be vague, often encompassing a range of different factors and potentially obscuring the multiple actors vying for influence within each of these institutions and any incoherence between the ideas and interests being promoted. For example, phrases employed by interviewees ranged from structural processes, such as 'globalisation', to ideological positions such as 'capitalism' and 'neo-liberalism', and social trends such as 'hyperconsumerism'. If there was a common thread linking the way in which these various phrases were used it seemed to be a belief that international corporations and financial institutions were increasingly framing the boundaries of acceptable policy discussions at the level of the nation-state. However, precisely which interests were involved, what they were trying to achieve and how remained vague in most interviews, despite some prompting.

As the quotation above illustrates, the interviewees who referred to 'globalising' processes seemed rather fatalistic about the prospect for change; for the most part, they appeared to be able to see no realistic way (at least in the relatively near future) in which policies at the national level could ever seriously challenge global economic processes and financial interests. In this sense, many of the interviewees' accounts of processes of globalisation and the dominance of neo-liberalism point to 
an acceptance of the idea that 'there-is-no-alternative' (TINA) to neo-liberal, market policies (see Centeno and Cohen, 2012; Munck 2003). Yet, as various authors are keen to point out (Larner 2003; Tickell and Peck 2003; Peck 2004), policies everywhere are not necessarily converging around very specific similarities but, rather, share 'certain family resemblances' (Peck 2004) or historical legacies (Larner 2003).

It is this process of the concealment of the complex heterogeneity underlying 'macro' concepts which seems essential to understanding the consistency with which many academic (and some other) interviewees' suggested that the dominant political and social 'contexts' were hostile to the reduction of health inequalities (or, at the very least, hostile to the implementation of policies they believed were likely to reduce health inequalities). Crucially, having been persuaded of the idea that 'governments' and/or of 'global financial organisations' represent powerful actors pursuing economic and policy objectives that are hostile to material and structural solutions to health inequalities, the data suggest interviewees' often decided to work within these objectives, rather than challenging them (even though many suggested that they felt these ideas and interests needed to be challenged for health inequalities to be reduced).

The best example of this is how interviewees talked about balancing their beliefs about health inequalities, and their evident (in almost all cases) desire to make some of practical difference, with their personal (material) career interests. Nearly all of the interviewees, across all sectors, recounted pitching their ideas to others (be that 
commissioners, managers or policy colleagues) in ways that they felt would enhance (or at least not diminish) their own professional credibility. So (as discussed in more elsewhere - Smith; 2013), health inequalities researchers described altering the way they presented ideas for policy audiences in ways which made this research less challenging to what they perceived to be the dominant policy trajectories (which, as we have seen above, were informed by their sense of ideas and interests being promoted by large financial interests). Civil servants described doing much the same when talking about how they pitched ideas to more senior colleagues, whilst the journalists and documentary makers I spoke to suggested that it would be pointless to pitch ideas that were too left-of-centre to editors or commissioners as they would simply be ignored:

Documentary maker: "[W]hen people talk about commissioners [of television documentaries at the BBC] they talk about what their political opinions are, actually [laughing] which is... ironic really because it [the BBC] is supposed to be impartial but, it's, 'oh, yeah, yeah, yeah, they like that,' you know what I mean? So you're really playing into what they... the subjects would then fit [perceptions of the commissioner's political views]"

Academic: 'I think one of the difficulties is often when there are bids for research funding [from policy related sources], it's almost if the findings or, you know, the messages that are required are stated from the start almost. [...] When one looks at research bids, it's, there are strong steers in terms of 
what they're looking for, what kinds of conclusions one's being steered towards, what kinds of policy messages they want...' [My emphasis]

Civil servant (Scotland): 'Special advisors... are... advising the Minister. [...] It's hard to get access to them 'cause they're busy people but you probably can get better access to them than to the Minister and it may well be a useful way of understanding what the Minister's thinking, through them. Equally, if you're trying to say to the Minister, 'look at this important evidence,' you wouldn't want the advisor going, 'what a load of old rubbish!' So it's important, from our perspective, for the advisor to say, 'it's credible and good.' So you know, it's, they've got an important part to play and we've got to think about how they'll respond.' [My emphasis]

In other words, interviewees across sectors suggested that their professional careers involved trying to guess what senior colleagues were 'looking for' (for academics, this was largely other academics, research funders, civil servants and ministers; for journalists it was editors; for documentary makers, it was commissioners; and for civil servants, it was policy advisors and ministers). These perceptions, in turn, appeared to be shaped by the beliefs described above; that health inequality is not an issue for which there is much political, public or media interest and that ideas associated with the need for a further redistribution of wealth are unpopular. In other words, interviewees described becoming what Larner $(2003, \mathrm{p} 4)$ terms 'acting subjects' - individuals who contribute to enacting (as well as challenging) the dominance of the neo-liberal and globalising processes that they describe (see Law 
and Urry 2004). For researchers, there appeared to be three common aspects to this, as summarised in Table 4.

Table 4: How researchers' accounts of their professional actions point to their enrolment in the perpetuation of dominant policy ideas

\begin{tabular}{|c|c|}
\hline Actions & $\begin{array}{l}\text { Illustrative quotation (all taken from interviews } \\
\text { with senior academics) }\end{array}$ \\
\hline $\begin{array}{l}\text { Developing research projects which fit } \\
\text { with / support existing policy objectives } \\
\text { (in order to increase chances of } \\
\text { obtaining funding) }\end{array}$ & $\begin{array}{l}\text { 'You get questions, in a purely scientific sense, you } \\
\text { get questions that you want to pursue. So what do } \\
\text { you do? You hang it on, one way or another, you } \\
\text { hang it as some issue that you think will get it } \\
\text { funded.' }\end{array}$ \\
\hline $\begin{array}{l}\text { Focusing on aspects of findings that are } \\
\text { least politically challenging }\end{array}$ & $\begin{array}{l}\text { "there were a couple of researchers who were in } \\
\text { this group I was in who said, basically, 'we don't } \\
\text { want to go there because that's too radical,' you } \\
\text { know, lets come up with something that's more } \\
\text { proximal because these distal determinants mean } \\
\text { that you're opening up what will be read as some } \\
\text { sort of socialist agenda." }\end{array}$ \\
\hline $\begin{array}{l}\text { Self-censorship (not being explicit about } \\
\text { ideas that are perceived to challenge the } \\
\text { dominant political context) }\end{array}$ & $\begin{array}{l}\text { "When I was [...] putting in for money on [blanked] } \\
\text { and health, we did produce papers which were - } \\
\text { how can I put it? We weren't coming out and } \\
\text { saying we were absolutely sure that [blank] causes }\end{array}$ \\
\hline
\end{tabular}


ill-health...'

Hence, although interviewees often presented themselves as having no control over the political context within which they worked (rather it was something which they had to 'work with'), their comments suggest that they were constantly engaged in interpreting this shifting context, which they then re-presented to other actors. This is evident in the following extract from a senior civil servant (with strong research links) who describes how he tries to encourage academics to work with the flow of the 'political tide':

Senior civil servant (Scotland): 'The critical thing is to try to get public health academics... having an effect on policy, but in turn having their activities shaped by policy aspirations. Not telling the academics what to do but saying, 'look, ministers are intent on going in this direction. Anyone want to follow and see what happens?' So that's kind of how we do it. [...] I made a very deliberate decision that if you were, if you're going to change things, you've got to work through the political process, you shouldn't work against the political process. Find the grain of the political, find what direction the political tide is running and try and surf with it.'

This quotation captures precisely the process via which this civil servant, as an individual who interacts with both ministers and researchers, positioned him/herself as a mediator of the political 'tide'; someone who encouraged researchers to work in ways that $\mathrm{s} /$ he perceived to be complementary to the existing direction of policy. 
The way in which the interviewee articulated this role suggests it was relatively passive, yet the acknowledgement that establishing the direction of this 'tide' is a process of exploration, rather than an interpretation of clear-cut directives, underlines that actors who work as 'interpreters' of the political 'context' actually play a translational role. That is, they enact their interpretations of political 'context' by trying to persuade others to act in line with their analyses. In fact, the interpretation of the path that policy was moving in frequently appeared to be something of a guessing game, often undertaken by individuals who had very little interaction with the actors they perceived to be influencing its direction.

When the interviewees involved in policymaking talked about the factors that informed their assessment of what the political 'context' was, they described trying to gauge what their senior policy colleagues might be thinking at least partly by considering the kinds of sources informing their colleagues' views. This often related to some sense of what the voting public wanted which was usually (imperfectly) filtered through popular mass media outlets (replaced in some of the more recent interviews by references to social media). For example:

Civil servant (England): 'I think perhaps the way that, if you like, the whole sort of social agenda has been underplayed, I think is in direct response to how it might be perceived in the media, you know, how News International might interpret it, or the Daily Mail, you know... People sort of think... politically, you might say, 'well that might undermine their credibility with... 
middle England,' which is... well, it's seen as being quite an important electoral... audience.'

Like the above civil servant, most of the interviewees based in policy suggested that the media played an extremely important role in shaping the direction of policy and, whilst most of these interviewees (including the one above) said they felt it was politicians and ministers who placed too much emphasis on what was reported in the media, many also appeared to reinforce its importance by relaying it to others. For example, a civil servant in Scotland explained $s /$ he felt that academic researchers ought to think 'a little bit more about the societal-political world we live in... and how it's driven by the media' if they wanted their work to influence policy. Both this statement and the above quotation illustrate the circular nature of interpretations of credibility; interviewees involved in the construction of policy described a process in which they assessed what was likely to be deemed 'credible' by their colleagues (particularly ministers and their advisors) based on an interpretation of what they felt would be deemed 'credible' amongst the audiences towards whom those actors were orientated. Policy-based interviewees who interacted with academic researchers then appeared to relay these interpretations to academics, with the aim of encouraging a flow into policy of research-based ideas that were likely to be deemed 'credible'. Meanwhile, many of the academic interviewees indicated that they consciously shaped their ideas in ways that they believed would be deemed 'credible' by policy audiences, by which they tended to be referring to civil servants and ministers (or, at least, in ways which would not damage their credibility). 
Although the analysis presented here remains a long way off the kinds of detailed studies that actor-network theorists usually undertake (e.g. Callon 1986; Latour 1988 [1984]), this section nonetheless hopefully begins to uncover how complex networks of actors and ideas operate in ways which give the appearance of a relatively uniform and authoritative political and social 'context'. The fact that many of the interviewees referred to singular actors ('the context', 'the government' or 'neoliberal ideology') demonstrates the effectiveness with which these networks were operating. Yet, it is also evident from the data that interviewees were actively helping to participating in the underlying networks and, therefore, helping to enact, or at least perpetuate, dominant ideas, even where they positioned themselves as critical of these ideas.

\section{The discursive power of economics}

The most important of these 'dominant ideas' referred to in the data appears to be the primacy of national economic growth, which interviewees frequently positioned an overarching policy aim to which the public largely subscribes and, therefore, a policy ambition which subsumes all others. This is particularly evident in aspects of the data in which the underlying motivation for reducing health inequalities (or improving population health) is articulated as the need to ensure that as many people as possible are contributing to the expansion of the national economy. This kind of logic was also evident in four of the interviews with policy-based individuals and the following quotation is the most overt example of this: 
Senior civil servant (Scotland): 'The Communities Minister has a part to play, the Education Minister, the Justice Minister - they all have a part to play in health [...] So what I need to do [...] is show them [...] that by delivering the agenda they want to deliver - safer streets, better educated children - they're actually delivering the agenda that I want and, by doing that, the next link in the chain I make is that, by delivering a healthier Scotland, we're ultimately delivering a wealthier Scotland.'

In the above extract, there is a clear assumption that it is somehow obvious and indisputable that securing economic wealth at the national level constitutes a key, motivating factor underlying every aspect of policymaking. The interviewee claims that the argument most likely to persuade both him/herself and his/her policymaking colleagues to tackle health inequalities is that there are economic advantages to doing so. It is noticeable that the interviewee at no point suggests there is a moral, ethical or human rights-based imperative to work towards the reduction in health inequalities. In other words, the extract suggests that the pursuit of national economic wealth operates as a 'meta-narrative' within policymaking (and, indeed, the data suggest, often beyond policy discourses to also shape broader public discourses). This suggests that the kind of 'economistic' campaign that Collini suggests took place in Britain in the second half of the twentieth century 'to make 'contributing to economic growth' the overriding goal of a whole swathe of social, cultural and intellectual activities which had previously been understood and valued in other terms' (Collini, 2011) has been successful. Once again, this speaks to the 
continuing relevance of Lukes' (1974) conceptualisation of the 'third' dimension of power.

In addition, however, the findings highlight the importance of language and the power of discourse, in a manner that is more reflective of post-structural, Foucauldian thinking. For example, as Table 5 illustrates, interviewees across the data set employed terms and phrases which demonstrated the ubiquity of economic discourses. Indeed, economic (particularly capitalist, competition-based) discourses appeared to have infiltrated almost all interviewees' accounts of their everyday professional lives.

Table 5: The dominance of economic terminology in interviewees' accounts of the circulation of ideas

\section{Illustrative quotations:}

Broadcast journalist: 'In terms of work, it [television] is not a particularly nice place to work. [...] It's all, 'where do you fit in the market?' It's not who you are as a person, it's... what do you provide for the market-driven economy? [...] Television is market driven. That's the way it goes, you know. I wish it wasn't, I wish it was a bit more like the nineteen-sixties, seventies and eighties, when there was a bigger scope for public service broadcasting, you know, and it was... the BBC was supposed to... inform, educate and entertain, but inform and educate was quite a big part, now it's just to entertain, even the news [laughs].' 
Civil servant (Scotland): 'If you don't have a team that's, well, it's marketing it [health inequalities]... It is marketing [...] Politicians need to be able to feel that they can make a difference and, therefore, you not only have to market it as being a problem, but you have to be able to market it as being something you can do something about.'

Academic: 'What's happened in health inequality [...] is that actually the doing of the... the scientific advisor role is a market, and that market is monopolized by certain people, in the same way as any good capitalist will try to, not necessarily monopolise but just like Tesco, you know, you want to fill up as much of that as possible and you don't want other people on your territory.' [...] We're all competing with each other the whole time. Everybody competes with everybody else for these markets for expertise and that is always going to cause problems. [...] I mean you run yourself like a small business.'

All of the interviewees quoted in Table 5 appear to position themselves as economic actors engaged in the marketing of ideas. It is clear that all three of these interviewees (and there are multiple other examples within the data) perceived themselves to be in competition with other sources of potential ideas. This has some important implications for the ways in which ideas about health inequalities are likely to have been constructed and promoted by individuals, possibly helping to explain the lack of any clear advocacy-coalition (see Sabatier and Jenkins-Smith, 1993) committed to reducing health inequalities (Smith, 2013). It also demonstrates that economic discourses have been so successfully translated across a range of contexts that they are employed even by interviewees who directly seek to challenge 
the domination of economic ideals over others in their work (as two of the interviewees quoted in Table 5 did, for example). In other words, some interviewees employed terminology derived from the very ideas (or ideologies) that they positioned themselves as challenging. The fact that it appears logical to employ economic terms when trying to communicate ideas which are not directly related to economics highlights the extent to which an orientation towards the importance of the economy has become embedded in the language that we use and, therefore, in the ways in which we think. This suggests that post-structural theories which, often inspired by Foucault (1982[1969]), conceive of power as discursive are also useful in understanding how we can all participate in the perpetuation of particular ideas through the language we employ and how difficult it can be to disentangle ourselves from ideas that have become normalised.

\section{Concluding discussion}

To date, explorations of 'political context' and health inequalities have tended to focus on assessing how particular categories of political context impact on health inequalities (e.g. Muntaner and Lynch 1999; Navarro and Shi 2001; Navarro, Muntaner et al. 2006; Navarro 2007; Schrecker and Bambra, 2015) and such approaches, as discussed, reflect a structural conceptualisation of power. It has not been the intention of this article to dismiss or critique this work but rather to take a different starting point to exploring this issue, by focusing on how a range of actors with an interest in health inequalities, involved in research, policy and the media, describe the political context of the UK (often labelled 'neoliberal') and the way in 
which they function within such a context. In so doing, it is hopefully clear that Marxist accounts of power (particularly Lukes' famous typology of power) continue to offer extremely useful explanatory insights for those with an interest in health inequalities. Indeed, several interviewees' accounts of the lack of media and public interest in health inequalities appeared to reflect precisely (and may have been informed by) this way of thinking about power, which helps explain why those most negatively affected by health inequalities might also be disengaged from debates about the underlying, unequal distribution of the social determinants of health.

However, this article argues that two key aspects of the findings point to the potential utility of post-structural accounts of power. The first of these comes in the section immediately preceding this concluding discussion, where the analysis highlights how economic terminology has infiltrated the language of interviewees. From a Foucauldian perspective, this is an example of discursive and linguistic power, in which actors may continually contribute (often unconsciously) to the reaffirmation of the ideas and assumptions that are dominant in the 'contexts' they inhabit. This suggests that health inequalities researchers perhaps ought to pay more attention to the language that they and others employ and to the work that language can do in perpetuating (and perhaps resisting) particular ideas and interests.

The second relates to the fact that the way many interviewees spoke about the political context evoked a sense of 'neoliberal' forces and actors that appear more 
cohesive than they necessarily are. This, as Latour points out, seems unhelpfully disempowering:

'If there is no way to inspect and decompose the contents of social forces, if they remain unexplained or overpowering, then there is not much that can be done. To insist that behind all the various issues there exists the overarching presence of the same system, the same empire, the same totality, has always struck me as an extreme case of masochism, a perverted way to look for sure defeat while enjoying the bittersweet feeling of superior political correctness.' (Latour 2005, p252)

Many of the interview accounts presented in this article attributed power to the kinds of overpowering social forces that Latour describes above and it is true that many of these interviewees then appeared to feel relatively powerless to challenge such forces. Indeed, some described how, in this context, they chose to pursue research projects, or present research findings, which did not challenge these dominant ideas. In so doing, such researchers were (consciously or unconsciously) helping to perpetuate ideas that they themselves argued needed to be challenged if we are to have any prospect of substantially reducing health inequalities.

It is not at all certain that post-structural accounts of power, evoking a sense of diffuse and sticky webs of ideas and interests are necessarily any more empowering; after all, it is difficult to analytically unpack these complex networks, let alone to disentangle ourselves sufficiently to pose a serious challenge to the dominant ideas 
and interests being enacted and perpetuated by broad constellations of actors. Nonetheless, if we are serious about the negative and unequal health implications of the various policy developments we collectively refer to as 'neoliberal' then we do need to get better at studying the specific actors, ideas and interests working to influence policy. To take inspiration from a particularly influential strand of public health, tobacco control, we need to do much more to understand (and make clear) the ways in which dominant ideas and evidence are shaped and promoted by particular interests (Smith, 2013). This is perhaps a first step in contributing to the production of spaces in which it is possible to feel more comfortable about thinking, and talking, critically about dominant ideas and interests that are negatively impacting on health inequalities. It would be a timely endeavour, since the recent upsurge of interest in inequality amongst economists (e.g. Piketty, 2014) and large financial institutions (e.g. OECD, 2-15) suggest the discursive terrain is already shifting in ways that may mean that the discussion of alternative ideas is becoming more feasible.

The argument being made here is that it may be fruitful to move beyond accounts of policymaking that suggest there is a unified consensus about particular political interests and objectives, which a small number of actors and institutions are engaged in promoting (either in the overt interests of 'elites' or through the unconscious inculcation of particular ideologies) to better acknowledge the complex networks of actors and ideas that are interacting in ways that give the impression of a coherent, monolithic project. This involves a post-structural conceptualisation of power as the outcome of collective action (Murdoch and Marsden, 1995) and it 
requires us to examine how this collective action comes about and to reflect on are own roles within this.

The question we perhaps ought to consider is whether, as Larner (2003) suggests, employing singular terms, such as 'neoliberal', as receptacles for quite heterogeneous policies and activities eclipses important complexities and tensions which, if brought more to the fore of our discussions, might serve to challenge (rather than reinforce) dominant ideas concerning, for example, the distribution of wealth, much as Foucauldian theorists such as Dean (2010) have done in relation to the more disciplinary dimensions of modern states. Moreover, if we reposition the 'macro-level' actors that many interviewees perceived to be 'blocking' the influence of health inequalities research as 'networks' (albeit smoothly functioning networks), do our own contributions to these networks (and, therefore, to the perpetuation of dominant ideas) become clearer? If so, might this help us resist our inculcation into particular ways of thinking and acting? These are not easy questions to answer but, at the very least, they hopefully attest to the potential value of post-structural theories of power for those committed to reducing health inequalities.

\section{References}

Allen, J. (1997) Economies of power and space. Chapter 5 in: Wills, J., Lee, R. (Eds.), Economic Geographies: Representations and Interpretations. London: Arnold. Bambra, C. and Schrecker, T. (2015) How Politics Makes Us Sick: Neoliberal 
Epidemics. Basingstoke: Palgrave Macmillan.

Black, D., Morris, J.N., Smith, C. and Townsend, P. (1980) Inequalities in Health Report of a Research Working Group. London: Department of Health and Social Services.

Blair, T. (2011) A Journey. London: Arrow.

Callon, M. (1986) Some Elements of a Sociology of Translation: Domestication of the Scallops and the Fishermen of St Brieuc Bay. In Law, J. Power, Action and Belief: A New Sociology of Knowledge. London: Routledge \& Kegan Paul: pp. 196-233.

Campbell, J. L. (2002) Ideas, Politics, and Public Policy. Annual Review of Sociology, 28: pp. 21-38.

Carlisle, S. (2001) Inequalities in health: contested explanations, shifting discourses and ambiguous policies. Critical Public Health, 11(3): 267 - 281.

Carmel, E. and Papadopoulos, T. (2003) The new governance of social security in Britain. In Millar, J. Understanding Social Security: Issues for Social Policy and Practice. Bristol: Policy Press.

Centeno, M. A. and Cohen, J.N. (2012) The Arc of Neoliberalism, Annual Review of Sociology, 38: 317-340.

Coburn, D. (2004) Beyond the income inequality hypothesis: class, neo-liberalism, and health inequalities. Social Science and Medicine 58: pp. 41-56.

Collini, S. (2011) From Robbins to McKinsey. Review of Higher Education: Students at the Heart of the System. London Review of Books [Online] vol. 33 no. 16 pp. 914. Available from http://www.Irb.co.uk/v33/n16/stefan-collini/fromrobbins-to-mckinsey [Accessed 3 June 2015]. 
Crawford, R. (1977) You are dangerous to your health: the ideology and politics of victim blaming. International Journal of Health Services: planning, administration, evaluation 7(4): pp. 663-680.

Dean, M. (2010) (2 ${ }^{\text {nd }}$ Ed.) Governmentality: Power and Rule in Modern Society. London: SAGE.

Foucault, M. (1982[1969]) The Archaeology of Knowledge. London: Vintage.

Katikireddi, S.V., Higgins, M., Smith, K.E. and Williams, G. (2013) Editorial: Health Inequalities - The Need to Move Beyond Bad Behaviours. Journal of Epidemiology and Community Health. 67: pp. 715-16.

Keck, M. and Sikkink, K. (1998) Activists Beyond Borders. Ithaca, New York: University Press.

Larner, W. (2003). Guest Editorial: Neoliberalism? Environment and Planning D: Society and Space 21(5): pp. 509-512.

Latour, B. (2005). Reassembling the Social: An Introduction to Actor-Network Theory. Oxford: Oxford University Press.

Latour, B. (1988 [1984]). The Pasteurization of France. London: Harvard University Press.

Law, J.N. (1992) Notes on the Theory of the Actor-Network: Ordering, Strategy, and Heterogeneity. Systemic Practice and Action Research 5(4): pp. 379-93.

Law, J. and Urry, J. (2004) Enacting the Social. Economy and Society, 33(3): pp. 390410

Levitas, R.A. (2004). Lets hear it for Humpty: social exclusion, the third way and cultural capital. Cultural Trends 13(2): pp. 41-56. 
Levitas, R.A. (2001) Against work: a utopian incursion into social policy. Critical Social Policy 21(4): pp. 449-465.

Lukes, S. (1974) Power: A Radical View. London: Macmillan.

Mackenbach, J.P. (2010) Has the English strategy to address health inequalities failed? Social Science \& Medicine 71: pp. 1249-53.

Mullin, C. (2010) A View from the Foothills: The diaries of Chris Mullin. London: Profile Books.

Munck, R. (2003) Neoliberalism, necessitarianism and alternatives in Latin America: there is no alternative (TINA)? Third World Quarterly 24(3): pp. 495-511.

Muntaner, C. and Lynch, J. (1999) Income Inequality, Social Cohesion, and Class Relations: A Critique of Wilkinson's Neo-Durkheimian Research Program. International Journal of Health Services 29(1): pp. 59-81.

Murdoch, J. \& Marsden, T. (1995) The spatialization of politics: local and national actor spaces in environmental conflict, The Transactions of the Institute of British Geographers, 20(3): pp. 368-380.

Navarro, V. and Shi, L. (2001) The political context of social inequalities and health. Social Science and Medicine 52: pp. 481-491.

Navarro, V., Muntaner, C. et al. (2006) Politics and health outcomes. Lancet 368: pp. 1033-1037.

Navarro, V. (Ed.) (2007) Neoliberalsim, Globalization and Inequalities: Consequences for Health and Quality of Life. Policy, Politics, Health and Medicine Series. Amityville, New York: Baywood.

OECD (2015) In It Together: Why Less Inequality Benefits All. Paris: OECD Publishing. 
Peck, J. (2004) Geography and public policy: constructions of neoliberalism. Progress in Human Geography 28(3): pp. 392-405.

Piketty, T. (2014) Capital in the Twenty-First Century. [Translated by Goldhammer, A.]. Cambridge, MA: Harvard University Press.

Sabatier, P.A., \& Jenkins-Smith, H.C.E. (1993) Policy Learning and Change: an advocacy coalition approach. Boulder, CO: Westview Press.

Scambler, G. (2007) Social structure and the production, reproduction and durability of health inequalities, Social Theory and Health, 5, 4, 297-315.

Scambler, G. (2009) Capitalists, workers and health: illness as a 'side-effect' of profitmaking, Social Theory and Health, 7, 2, 117-28.

Scott-Samuel, A. (2004) New Labour's new idea - Health promotion. Liverpool: Politics of Health Group.

Smith, K.E. (2013) Beyond Evidence Based Policy in Public Health: The Interplay of Ideas. Basingstoke: Palgrave Macmillan.

Smith, K.E. and Kandlik Eltanani, M. (2015) What kinds of policies to reduce health inequalities in the UK do researchers support? Journal of Public Health. 37(1): 6-17.

Tickell, A. and Peck, J. (2003). Making global rules: globalization or neoliberalization? In Peck,J. and Yeung, H.C-W. Remaking the Global Economy: Economicgeographical perspectives. London: Sage: pp. 163-181. 